Int. Archs Allergy appl. Immun. 1980;62:I-VI

\title{
Contents, Vol. 62, 1980
}

\section{No.l}

Original Paper

Mediators of Immune Complex-Induced Aggregation of Polymorphonuclear Neutrophils. I. C5a

Anaphylatoxin, Neutrophil Cationic Proteins and Their Cleavage Fragments

Camussi, G.; Tetta, C; Bussolino, F.; Caligaris Cappio, F.; Coda, R.; Masera, C, and

Segoloni, G 1

Immunogenicity of Tobacco Smoke Components in Rabbits and Mice

Lehrer, S. B.; Wilson, M. R., and Salvaggio, J. E 16

Parasite-Reactive Serum IgE Antibodies in African Populations. Relation to Intestinal Parasite Load

Revoltella, R.; Jayakar, S. D.; Tinelli, M.; Scaglia, M.; Peracino, A.; Desmarais, J. C, and

Siccardi, A. G 23

The Nature of Secretory Agglutinins and Aggregating Factors. III. Secretory Conglutinin-Like Factor SKF Detects a Cross-Reaction between Bacteria and Complement Component C3

Eggert, F. M 34

The Nature of Secretory Agglutinins and Aggregating Factors. IV. Complexing between NonMucin Glycoproteins, Immunoglobulins and Mucins in Human Saliva and Amniotic Fluid

Eggert, F. M 46

Lymphotoxins: Selective Cytotoxic Effects

Lisafeld, B. A.; Minowada, J.; Klein, E., and Holtermann, O. A 59

Effect of Adult Thymectomy on the Development of l-Chloro-2,4-Dinitrobenzene Contact

Sensitivity and Other T Lymphocyte Functions in Patients with Myasthenia gravis

Roupe, G.; Lindholm, L., and Hanson, L. A 67

Mummies from Peru. Demonstration of Antigenic Determinants of Collagen in the Skin

Wick, G.; Haller, M.; Timpl, R.; Cleve, H., and Ziegelmayer, G 76

Reduction of a Subset of T Cells Bearing Fc Receptors for IgG in Lepromatous Leprosy

Singh, S. and Nath, 181

Homocytotropic Antibody Responses during Murine Schistosomiasis. A Follow-Up Study of Both Total Immunoglobulins and Schistosoma mansoni Specific Antibodies

Rousseaux-Prévost, R.; Bout, D.; Bazin, H., and Capron, A 86

Spleen Hemolytic Plaque-Forming Cell Response and Generation of Cytotoxic Cells in

Genetically Obese (C57B1/6J ob/ob) Mice

Chandra, R. K. and Au, B 94

Specificity of Fc Receptors on Human Monocytes for IgGl and IgG3

Alexander, M. D 99

Trichinella spiralis Infection in Animals Genetically Selected for High and Low Antibody

Production. Studies on Intestinal Pathology

Ruitenberg, E. J.; Perrudet-Badoux, A.; Boussac-Aron, Y., and Elgersma, A 104 
Specificity of Receptors for IgG on Human Cytotoxic Plaque-Forming Mononuclear Leukocytes. Induction and Inhibition of Plaque-Forming Activity

Thorsteinsson, L.; Michaelsen, T. E., and Frøland, S. S $\quad$ Ill

Short Communication

Biological Variation in the Immunological Release of Histamine from Replicates of Passively

Sensitized Human Lung and Its Relation to Histamine Content

Coleman, J. W 118

IV

Contents

No. 2

Original Paper

Dose Response with Sensitizing Antibody in EA Rosette Formation

Loren, A. B.; Horita, M.; Tseng, C. H., and Yokoyama, M. M 121

Enhancement of the Human Mixed Lymphocyte Culture Response by Pretreating the Stimulating

Cells with Interferon

Einhorn, S. and Blomgren, H 126

Antibody-Independent Complement Consumption by Micropolyspora Faeni

Marx, J. J., Jr.; Motszko, C, and Roberts, R. C 133

Secretion of a Hyperemia-Inducing Moiety by Mitogen or Glycogen Stimulated Mononuclear

Inflammatory Cells of Sheep and Rabbit

Vadas, P. and Hay, J. B 142

Enhancement of NK, but not K Cell Activity by Different Interferons

Rumpold, H.; Kraft, D.; Scheiner, O.; Meindl, P., and Bodo, G 152

Proliferative Response of Lymphocytes of Normal Individuals to Wheat Proteins (Gliadins)

Frew, A. J.; Bright, S.; Shewry, P. R., and Munro, A 162

Localization of 125I-Labeled DNP-Ficoll on Lymphoid Cells from the Normal and Defective Hybrid Progeny of CBA/N Mice

Snippe, H; Merchant, B.; Lizzio, E. F., and Inman, J. K 168

Rapid Batch Fractionation of Ryegrass Pollen Allergens

Smart, I. J. and Knox, R. B 179

Studies on Lymphokine-Induced Macrophage Aggregation. Specificity and Quantitative Aspects Badenoch-Jones, P.; Rouveix, B., and Turk, J. L 188

Rat Passive Peritoneal Anaphylaxis Following Sensitisation with Guinea Pig Antíserum: an Immediate Hypersensitivity Reaction without Histamine Release

Smith, H.; Ross, J. W., and Spicer, B. A 195

Histamine-Containing Cells from Bronchial Lavage of Macaque Monkeys. Time Course and Inhibition of Anaphylactic Histamine Release

Butchers, P. R.; Vardey, C. J.; Skidmore, I. F.; Wheeldon, A., and Boutal, L. E. 205

Experiments in Mice and Rats on the Induction of Joint Lesions following Injections of Serum and in Chronic Virus Infection

Oldham, G.; Poole, A. R.; Brownson, J. M.; Mahy, B. W. J., and Coombs, R. R. A

Stimulation of Neutrophil Locomotion by Inosiplex

Patrone, F. and Dallegri, F 221

Experimental Erythrocyte Autoimmunity. II. Autoantibody-Specific Suppressor Cells Present in Blood

Care, N. F. and Cox, K. $0 \quad 227$ 
Short Communications

Detection of Autoimmune Response to Rabbit Epididymal and Seminal Spermatozoa

Riera, C. M.; Galmarini, M.; Faillaci, M. G., and Yantorno, C 231

Graft-versus-Host Reactions against H-Y Antigen

Kuroiwa, A.; Nagino, H.; Miyazaki, S.; Nomoto, K., and Goya, N 235

Announcements 240

Contents

$\mathrm{V}$

No. 3

Original Paper

Immunogenicity of Ovalbumin-Ficoll Conjugates with Particular Reference to IgE Antibody

Production

Carter, B. G

Antibodies against Aspergillus fumigatus. I. Standardization of the Antigenic Composition

Kauffman, H. F. and Vries, K. de 252

Antibodies against Aspergillus fumigatus. II. Identification and Quantification by Means of

Crossed Immunoelectrophoresis

Kauffman, H. F. and Vries, K. de 265

T-Cell-Priming Characteristics of Modified Timothy Grass Pollen Antigen B

Malley, A.; Begley, D. E., and Forsham, A 276

Extended Evaluation of Allergic Bronchopulmonary Aspergillosis

Ghory, A. C; Patterson, R.; Greenberger, P., and Roberts, M 285

Effect of Different Dietary Lipids on the Immune Responses of Hartley Strain Guinea Pigs

Friend, J. V.; Lock, S. O.; Gurt, M. I., and Parish, W. E 292

Variability in Generation of Anti-Sheep Erythrocyte Plaque-Forming Cells from Cultures of Human Peripheral Blood. Influence of Monocytes

Hollingsworth, J. W.; Dunne, J. V.; Small, D,; Rose, J. E., and Vaughan, J. H 302

Characterization of a Sperm-Specific Antigen in Inbred Strains of Rats

Weinblatt, A. C; Gill, T. J., Ill, and Kunz, H. W 309

In vitro Effects of Synthetic Chemotactic Peptides on Neutrophil Function

Patrone, F.; Dallegri, F.; Bonvini, E., and Sacchetti, C. 316

A Variation of the Radioimmune Assay

Keese, C. R. and Giaever, 1324

Inability of Intravenously Injected Monocellular Suspensions of Human Bone Marrow to

Establish in the Nude Mouse

Ganick, D. J.; Sarnwick, R. D.; Shahidi, N. T., and Manning, D. D. 330

Studies in Acute Leukemia. II. Chemotaxis of Leukemic Blasts from Patients with Acute

Nonlymphoid Leukemia: Its Relationship with IgG Fc Receptors and Role of Surface-Bound Immunoglobulin

Gupta, S.; Garrett, T.; Straus, D., and Good, R. A 334

Inflammatory Potency of Antigen-Antibody Complexes and C-Reactive Protein in a Wound Chamber Model in Rats

Ahlstedt, S 341

Demonstration and Quantification of IgE Antibodies Against Paracoccidioides brasiliensis in Paracoccidioidomycosis

Yarzábal, L.; Dessaint, J. P.; Arango, M.; Albornoz, M. C. B. de, and Campins, H 346 
Quantitative Studies on Immunofluorescent Staining. VII. Fractionation of Conjugates by Acid Dialysis to Reduce Nonspecific Staining

Binder, W. L. and Beutner, E. H 352

Short Communication

Local Anaphylactoid Responses in Rats

West, G. B 355

Letter to the Editors 359

VI Contents

No. 4

Original Paper

Effect of Experimental Dengue Virus Infection on Humoral and Cell-Mediated Immune

Response to Thymus-Dependent Antigen

Nagarkatti, M.; Nagarkatti, P. S., and Rao, K. M 361

Radiosensitivity of Non-Primed and Primed Human T Cells in vitro

Onsrud, M. and Thorsby, E 370

Inhibition of Murine Reaginic Antibody Responses by Nasal Immunotherapy with Modified Allergen

Schumacher, M. J. and Mitchell, G. F 382

Suppression of IgE Antibody Formation in Mice with Nonspecific Stimulation

Itaya, T.; Tomioka, H.; Kumagai, A., and Tada, T 389

Pharmacological and Immunological Aspects of Histamine Release from Horse Leucocytes

Kings, M. A. and Week, A. L. de 397

Dissociation between Humoral and Cellular Responses to PPD after BCG Vaccination

Neveu, P. J.; Buscot, N., and Soulillou, J. P 409

Interaction of the Antiallergic Agent AA-344 with Biogenic Amines and Prostaglandins in

Production of Cyclic AMP in Rat Mast Cells

Ashida, Y.; Saijo, T.; Kuriki, H., and Maki, Y

Studies on Immune Response to Mycobacterium lepraemuriiim. Evaluation of the Cell-Mediated Immune Response in Mice

Navalkar, R. G.; Patel, P. J., and Kanchana, M. V 423

Nonparticipation of $\mathrm{Cl}$ q in the Decrease of Complement Activity in the Cold in Sera of Patients with Chronic Liver Diseases

Yoshida, H.; Morito, T.; Onizawa, N., and Kasukawa, R 433

Comparison of Venom and Whole-Body Rast and Intradermal Testing in Vespid-Sensitive

Patients

Meriney, D.; Nail, T.; Wallace, D.; Rosenzweig, D.; Goel, Z., and Grieco, M. H 442

Reversible Suppression of Allo-Antibody Production by Cyclosporin A

Denham, S.; Styles, J. M.; Barfoot, R. K., and Dean, C. J 453

Short Communications

Influence of Pregnancy on the Immune Response to Ragweed Antigen in Rats

Vijay, H. M.; Buttare, H. S., and Lavergne, G

Influence of Dextran Polymer Particles (Sephadex G-200) on Humoral Immune Responses

Ernst, T.-M., Gillert, K.-E. and Müller, S 463

Calcium Pools Involved in Histamine Release from Rat Mast Cells

Ennis, M.; Truneh, A.; White, J. R., and Pearce, F. L 467

Book Review 472 
Author Index 473 